\title{
Effect of Compost, Ascorbic Acid and Salicylic Acid Treatments on Growth, Yield and Oil Production of Fennel Plant
}

\author{
Ali, A.F.; E.A. Hassan; E.H. Hamad and W.M.H. Abo-Quta
}

Dept. Horticulture, Fac. Agric., Al-Azhar University, Assiut, Egypt

Received on: 19/10/2016

Accepted for publication on: 23/10/2016

\begin{abstract}
The present work was conducted during the two successive seasons of $2012 / 2013$ and 2013/2014 to determine the effect of organic fertilization, foliar spray with ascorbic acid and salicylic acid as well as their interactions on growth, yield and oil production of fennel. Organic fertilizer was plant compost at 0,8 , 16 and $24 \mathrm{~m}^{3} / \mathrm{fed}$. The plants were sprayed with ascorbic acid and salicylic acid each at $0,50,100$ and $200 \mathrm{ppm}$. The revealed results indicated that utilizing organic manure increased herb dry weight/plant, number of umbels/plant, fruit yield/plant and yield/fed. Volatile oil \% and volatile oil yield/plant and per fed. The highest values of such parameters were obtained by adding compost at the high level ( $24 \mathrm{~m}^{3} /$ fed.). In most cases, spraying fennel plants with ascorbic acid or salicylic acid improved plant growth, fruit yield and oil production. Foliar spray with ascorbic acid at 100 ppm gave the maximum values of herb dry weight, fruit yield and volatile oil yield. The highest values of umbel number/plant were occurred by using ascorbic acid at $200 \mathrm{ppm}$ in the first season and salicylic acid at $100 \mathrm{ppm}$ in the second one. The application of ascorbic acid at $200 \mathrm{ppm}$ registered the maximum values of volatile oil \%. With regard to the interaction, the most of combined treatments showed a significant increase in all examined characters. The addition of compost at the high level $\left(24 \mathrm{~m}^{3} / \mathrm{fed}\right.$.) plus $100 \mathrm{ppm}$ ascorbic acid gave the highest values of herb dry weight, number of umbels/plant, fruit yield and volatile oil yield. While, the use of compost at the high level in combination with $200 \mathrm{ppm}$ ascorbic acid recorded the maximum values of volatile oil \%. From the obtained results, it could be recommended, to supply fennel plants with plant compost at $24 \mathrm{~m}^{3} /$ fed in combination with foliar spray with ascorbic acid at $100 \mathrm{ppm}$ to obtain better growth, high yield of fruit and volatile oil under this investigation conditions.
\end{abstract}

\section{Introduction}

Fennel (Foeniculum vulgare Mill) is an annual, biennial or perennial aromatic herb, depending on the variety, it belongs to Apiaceae Family (Farrell,K.T. (1988) and Wichtl and Bissel, 1994). It is widely cultivated as medicinal and aromatic plants in many countries including Egypt particularly in Middle Egypt such as El-Minia and Assiut governorates. The fruits contain essential oil which is utilized as carminative, flavoring agents and laxative preparations (Lawless, 1997). The fennel has been used in medicinal folklore as carminative, sedative stimulant and diuretic (Charles et al., 1993) and galactogogic, expectorant, emmenagogic and antispasmodic (Chiej, R. 1984). The oil contains a main compound namely fenchone that plays an important role in pharmaceutical, in- 
dustries and confectionery (Abdallah et al., 1978).

Abou El-Fadl et al. (1990) reported that in order to augmenting the quality of crops especially medicinal and aromatic plants, the application of organic fertilization is more acceptable than mineral fertilization and organic farming have been quality standard to be matched well by small farmers in Egypt. The positive role of organic fertilization in increasing herb dry weight, umbels number, seed yield, volatile oil $\%$ and volatile oil yield were obtained by several investigators such as Badran and Safwat (2004), Mohamed and Ahmed (2003), Abdou and Mohamed (2003), Sharaf and Khatab (2004) and Azzaz et al. (2009) on fennel, Abou-Aly and Gomaa (2002), and Radwan and Farahat (2002), Abd El-Gawad (2007) and Rekaby (2013) on coriander, Shaalan (2005) and Somida et al. (2001) on Nigella sativa, Ali et al. (2014) on Cassia acutifolia and Hassan et al. (2015) on rosemary.

The efficiency of antioxidant such as salicylic acid and ascorbic acid in enhancing herb dry weight, umbels number, seed yield, volatile oil $\%$ and yield was studied by many authors, concerning salicylic acid applciatoin, Ali (2004) on Tagetes minuta, Hassan et al. (2010), Badran et al. (2011 and 2013) and Rekaby (2013) on coriander, Al-Shareif (2006), Abd El-Naeem (2008) and Eshak (2013) on caraway, Abdou et al. (2012) on cumin, Tanious (2008) on fennel and Hemdan (2008) on anise.

As for ascorbic acid, Ali et al. (2003), Badran et al. (2011 and 2013) and Rekaby (2013) on coriander, Ali et al. (2006) on anise, Al-Shareif (2006), Abd El-Naeem (2008) and Eshak (2013) on caraway, Gahory (2012) on Nigella ativa, Tanious (2008) on fennel and Kenawy (2010) on Ammi visnaga.

The aim of this work was to study the influence of organic fertilization and some antioxidants (salicylic acid and ascorbic acid) and their interactions on grotw, fruit yield and oil production of fennel.

\section{Materials and Methods}

The present study was conducted at the Experimental Farm, Fac. of Agric., Al-Azhar Univ., Assiut, during the two successive seasons of 2012/2013 and 2013/2014 to determine the influence of organic fertilization and some antioxidants namely, ascorbic acid and salicylic acid as well as their interactions on fennel (Foeniculum vulgare Mill) plant.

The experiment was arranged in split plot design with three replications, the main plots included compost (plant residues) as organic fertilizer levels whereas, and ascorbic acid and salicylic acid concentrations considered the sub-plots. Fennel seeds were obtained from Medicinal and Aromatic Plants Department, Agricultural Research Center, Egypt. The seeds were sown on Nov. $5^{\text {th }}$ for the two seasons in $2 \times 1.8 \mathrm{~m}$ plot containing 3 rows, $40 \mathrm{~cm}$ apart in hills, 60 $\mathrm{cm}$ apart on one side of the ridge. The growing seedlings were thinned to two plants/hill after 45 days from the planting date. Accordingly, the experimental unit contained 30 plants. Physical and chemical properties of the experimental soil are shown in Table (1). The utilized compost were 
obtained from Pharaohs Factory for the production of compost, Wasti, Beni Suef, Egypt, and the chemical analysis of it was illustrated in Table (2). The used materials (ascorbic acid and salicylic acid) were obtained from Gomhoria company, Egypt. Such organic manure was added during preparing the soil for sowing in both seasons at four levels as follows:

1- control. 2- $8 \mathrm{~m}^{3} / \mathrm{fed}$. 3- 16 $\mathrm{m}^{3} /$ fed. $4-24 \mathrm{~m}^{3} /$ fed. The plants were foliar sprayed with ascorbic acid and salicylic acid each at concentrations of 0, 50, 100 and $200 \mathrm{ppm}$ three times at two week intervals starting January $10^{\text {th }}$ of the two experimental seasons, one day period was allowed between the spraying of the two materials. All agricultural practices were performed as usual. At the harvesting time on the first week of May in both seasons, the following data were recorded: herb dry weight ( $g / p$ lant), number of umbels/plant, fruit yield (g/plant), fruit yield ( $\mathrm{kg} /$ fed.), essential oil \% in the fruits, then essential oil yield (ml/plant) and liter/fed. were calculated. The essential oil in the fruits of fennel plant was extracted and determined according to the method described by Guenther (1961). All obtained data were statistically analyzed according to Little and Hills (1978).

Table 1. The physical and chemical properties of the used Soil (Average the two seasons).

\begin{tabular}{|c|c|c|c|c|c|c|c|c|c|c|c|c|}
\hline \multirow[b]{2}{*}{ Texture } & \multirow[b]{2}{*}{$\begin{array}{c}\text { PH } \\
(1: 2.5)\end{array}$} & \multirow[b]{2}{*}{$\begin{array}{c}\text { E.C. } \\
(\mathrm{m} . \mathrm{mohs} / \mathrm{cm})\end{array}$} & \multirow{2}{*}{$\begin{array}{c}\mathrm{CaCo}_{3} \\
\%\end{array}$} & \multirow{2}{*}{$\begin{array}{c}\text { O.M } \\
\%\end{array}$} & \multirow{2}{*}{$\begin{array}{c}\text { Total } \\
\text { N } \\
\%\end{array}$} & \multicolumn{2}{|r|}{ Available } & \multicolumn{5}{|c|}{$\begin{array}{c}\text { Water soluble Ions } \\
\text { (meq/L) in the soil paste }\end{array}$} \\
\hline & & & & & & $\begin{array}{c}\mathbf{P} \\
\text { ppm }\end{array}$ & $\begin{array}{c}\mathrm{K} \\
(\mathrm{mg} / 100 \mathrm{~g} \text { soil })\end{array}$ & $\mathbf{C a}$ & Mg & $\begin{array}{l}\mathrm{Co}_{3+} \\
\mathrm{HcO}_{3}\end{array}$ & CL & $\mathrm{SO}_{4}$ \\
\hline Loamy & 7.5 & 2.2 & 2.53 & 0.50 & 0.12 & 0.14 & 3.5 & 3.4 & 1.9 & 2.9 & 2.2 & 6.6 \\
\hline
\end{tabular}

Table 2. The chemical analysis of the used compost. (Average the two seasons).

\begin{tabular}{|l|c|}
\hline Content & Compost (plant residues) \\
\hline PH & 7.0 \\
\hline E.C.(m.mhos/cm.) & 1.94 \\
\hline Organic matter \% & 37.0 \\
\hline Organic carbon \% & 18.9 \\
\hline C : N Ratio & $12: 1$ \\
\hline Total nitrogen \% & 1.20 \\
\hline Total phosphorus \% & 1.25 \\
\hline Total potassium\% & 1.05 \\
\hline Fe ppm & 2397 \\
\hline Mn ppm & 241 \\
\hline Zn ppm & 46 \\
\hline Cu ppm & 13 \\
\hline
\end{tabular}




\section{Results and Discussion}

\section{Herb dry weight (g)/plant:}

The present data in Table (3) revealed that supplying fennel plants with organic manure as compost at all levels in the two experimental seasons, except the low and the medium ones in the second season led to a significant augment in herb dry weight compared to untreated plants. It is obvious that the high level of compost $\left(24 \mathrm{~m}^{3} / \mathrm{fed}\right.$. $)$ registered the heaviest herb dry weight which increased it by $16.8 \%$ and by $11.8 \%$ over the check treatment in the first and second seasons, respectively. The positive effect of organic fertilization on enhancing the herb weight was obtained by Badran and Safwat (2004) Mohamed and Ahmed (2003) and Tanious (2008) and Abdou et al. (2012) on fennel and Rekaby (2013) on coriander.

with regard to antioxidant treatments, the listed data in Table (3) declared that spraying the plants with ascorbic acid and salicylic acid at all concentrations, except, $50 \mathrm{ppm}$ salicylic acid in both seasons caused a significant increase in herb dry weight/plant in comparison with unsprayed plants in both seasons. From the obtained results, it is clear that the medium concentration of ascorbic acid $(100 \mathrm{ppm})$ gave the maximum value of this trait as ranged $25.2 \%$ and $27.4 \%$ over control in the first and the second seasons, respectively.

The capability of ascorbic acid on increasing herb dry weight was detected by Tanious (2008) on fennel, Ali et al. (2003) and Badran et al. (2011 and 2013) and Rekaby (2013) on coriander and Ali et al. (2006) on anise.

The role of salicylic acid on augmenting herb dry weight was noticed by Tanious (2008) on fennel, Hemdan (2008) on anise and Abd ElNaeem (2008) and Eshak (2013) on caraway.

The interaction effect between the two studied factors on herb dry weight of fennel was significant in both seasons (Table3). The most combined treatments significantly increased herb dry weight compared to untreated ones in the two seasons. Obviously, the heaviest herb dry weight/plant was observed by using $24 \mathrm{~m}^{3} /$ fed compost plus foliar sprays with ascorbic acid at $100 \mathrm{ppm}$ comparing to the other combination treatments in the two seasons. 
Table 3. The influence of compost levels and treatments of ascorbic and salicylic acids on herb dry weight (g)/plant of fennel during 2012/2013 and 2013/2014 seasons.

\begin{tabular}{|c|c|c|c|c|c|c|}
\hline \multicolumn{7}{|c|}{ First season } \\
\hline \multirow{2}{*}{\multicolumn{2}{|c|}{$\begin{array}{l}\text { Antioxidant } \\
\text { concentrations } \\
\text { (B) ppm }\end{array}$}} & \multicolumn{4}{|c|}{ compost levels (A) } & \multirow{2}{*}{$\begin{array}{l}\text { Mean } \\
\text { (B) }\end{array}$} \\
\hline & & Control & $8 \mathrm{~m}^{3}$ & $16 \mathrm{~m}^{3}$ & $24 \mathrm{~m}^{3}$ & \\
\hline Cont & $\mathbf{0}$ & 84.3 & 91.5 & 97.0 & 106.3 & 94.8 \\
\hline \multirow{3}{*}{$\begin{array}{l}\text { Ascorbic } \\
\text { acid }\end{array}$} & 50 & 100.3 & 103.8 & 107.3 & 109.8 & 105.3 \\
\hline & 100 & 111.6 & 122.3 & 114.0 & 127.0 & 118.7 \\
\hline & 200 & 109.3 & 114.0 & 117.6 & 126.0 & 116.7 \\
\hline \multirow{3}{*}{$\begin{array}{c}\text { Salicylic } \\
\text { acid }\end{array}$} & 50 & 83.3 & 94.3 & 98.0 & 109.3 & 96.2 \\
\hline & 100 & 90.6 & 98.6 & 102.0 & 111.6 & 100.7 \\
\hline & 200 & 94.6 & 102.6 & 104.0 & 97.3 & 99.6 \\
\hline \multicolumn{2}{|c|}{ Mean (A) } & 96.3 & 103.9 & 105.7 & 112.5 & \\
\hline \multicolumn{2}{|c|}{ L.S.D $_{(0.05)}$} & $\mathbf{A}=$ & & $B=3.7$ & & 7.4 \\
\hline \multicolumn{7}{|c|}{$\begin{array}{l}\text { Second season } \\
\end{array}$} \\
\hline \multirow{2}{*}{\multicolumn{2}{|c|}{$\begin{array}{c}\text { Antioxidant } \\
\text { concentrations } \\
\text { (B) }\end{array}$}} & \multicolumn{4}{|c|}{ compost levels (A) } & \multirow{2}{*}{$\begin{array}{c}\text { Mean } \\
\text { (B) }\end{array}$} \\
\hline & & Control & $8 \mathrm{~m}^{3}$ & $16 \mathrm{~m}^{3}$ & $24 \mathrm{~m}^{3}$ & \\
\hline Contr & $\mathbf{0}$ & 96.0 & 98.6 & 103.6 & 112.5 & 102.7 \\
\hline \multirow{3}{*}{$\begin{array}{l}\text { Ascorbic } \\
\text { acid }\end{array}$} & 50 & 114.1 & 104.0 & 108.5 & 115.0 & 110.4 \\
\hline & 100 & 127.2 & 135.3 & 126.5 & 134.4 & 130.9 \\
\hline & 200 & 119.6 & 123.0 & 127.2 & 129.8 & 124.9 \\
\hline \multirow{3}{*}{$\begin{array}{c}\text { Salicylic } \\
\text { acid }\end{array}$} & 50 & 96.6 & 96.6 & 104.0 & 114.2 & 102.9 \\
\hline & 100 & 99.0 & 105.0 & 107.0 & 117.9 & 107.2 \\
\hline & 200 & 103.3 & 108.0 & 112.3 & 121.0 & 111.2 \\
\hline \multicolumn{2}{|c|}{ Mean (A) } & 108.0 & 110.1 & 112.7 & 120.7 & \\
\hline \multicolumn{2}{|c|}{ L.S.D $(0.05)$} & \multicolumn{2}{|c|}{$A=5.1$} & $B=4.4$ & \multicolumn{2}{|c|}{$\mathrm{AB}=8.8$} \\
\hline
\end{tabular}

Number of umbels/plant:

Data in Table (4) showed that number of umbels/plant of fennel was significantly increased compared to control in both seasons due to fertilizing the plants with compost at all levels, except the low one $\left(8 \mathrm{~m}^{3} / \mathrm{fed}\right)$ in the first season compared to the check treatment. It seems that the ap- plication of higher level of compost gave the highest value of umbels number/plant reached $28.3 \%$ and $25.7 \%$ over unfertilized plants in the firest and second seasons, respectively. The increment of umbels number/plant as result of utilizing organic manure was reported by Badran 
and Safwat (2004), Tanious (2008) and Azzaz, et al. (2009) on fennel.

Concerning ascorbic acid and salicylic acid treatments, data reveals that all concentrations of both substances, except 200 ppm salicylic acid in the first season and $50 \mathrm{ppm}$ ascorbic acid in the second one led to a significant augment in number of umbels/plant. Compared to unsprayed plants in the two seasons. It was found that foliar sprays with ascorbic acid at $200 \mathrm{ppm}$ in the first season recorded the highest number of umbels/plant comparing to the other treatments.

In the second season, the use of $100 \mathrm{ppm}$ salicylic acid gave the high- est value of umbels number/plant comparing to other treatments. These superior treatments increased umbels number/plant by $28.8 \%$ and $20.6 \%$ over the check treatment in the first and second seasons, respectively (Table 4). The efficiency of ascorbic acid on enhancing number of umbels was insured by Tanious (2008) on fennel, Kenawy (2010) on Ammi risvaga and Rekaby (2013) on coriander. The positive effect of salicylic acid in augmenting number of ambles was studied by Tanious (2008) on fennel, Hemdan (2008) on anise and Rekaby (2013) on coriander.

Table 4. The influence of compost levels, and treatments of ascorbic and salicylic acids on number umbels/plant of fennel during 2012/2013 and 2013/2014 seasons.

\begin{tabular}{|c|c|c|c|c|c|c|}
\hline \multicolumn{7}{|c|}{ First season } \\
\hline \multirow{2}{*}{\multicolumn{2}{|c|}{$\begin{array}{c}\text { antioxidant } \\
\text { concentrations } \\
\text { (B) ppm }\end{array}$}} & \multicolumn{4}{|c|}{ compost levels (A) } & \multirow{2}{*}{$\begin{array}{c}\text { Mean } \\
\text { (B) }\end{array}$} \\
\hline & & Control & $8 \mathrm{~m}^{3}$ & $16 \mathrm{~m}^{3}$ & $24 \mathrm{~m}^{3}$ & \\
\hline \multicolumn{2}{|c|}{ Control 0} & 32.5 & 33.5 & 35.1 & 41.7 & 35.7 \\
\hline \multirow{3}{*}{$\begin{array}{l}\text { Ascorbic } \\
\text { acid }\end{array}$} & 50 & 33.4 & 34.3 & 41.2 & 51.0 & 40.0 \\
\hline & 100 & 40.9 & 39.8 & 44.6 & 54.0 & 44.8 \\
\hline & 200 & 44.5 & 44.1 & 47.5 & 48.0 & 46.0 \\
\hline \multirow{3}{*}{$\begin{array}{l}\text { Salicylic } \\
\text { acid }\end{array}$} & 50 & 31.8 & 37.2 & 38.3 & 41.5 & 37.2 \\
\hline & 100 & 38.4 & 41.1 & 45.0 & 50.8 & 43.8 \\
\hline & 200 & 33.1 & 34.0 & 37.3 & 40.2 & 36.2 \\
\hline \multicolumn{2}{|c|}{ Mean (A) } & 36.4 & 37.7 & 41.3 & 46.7 & \\
\hline \multicolumn{2}{|c|}{ L.S.D ${ }_{(0.05)}$} & \multicolumn{2}{|c|}{$\mathrm{A}=1.5$} & $\mathrm{~B}=1.4$ & \multicolumn{2}{|c|}{$\mathrm{AB}=2.9$} \\
\hline \multicolumn{7}{|c|}{$\begin{array}{l}\text { Second season } \\
\end{array}$} \\
\hline \multirow{2}{*}{\multicolumn{2}{|c|}{$\begin{array}{l}\text { antioxidant } \\
\text { concentrations } \\
\text { (B) ppm }\end{array}$}} & \multicolumn{4}{|c|}{ compost levels $(A)$} & \multirow{2}{*}{$\begin{array}{l}\text { Mean } \\
\text { (B) }\end{array}$} \\
\hline & & Control & $8 \mathrm{~m}^{3}$ & $16 \mathrm{~m}^{3}$ & $24 \mathrm{~m}^{3}$ & \\
\hline \multicolumn{2}{|c|}{ Control 0} & 33.6 & 38.1 & 40.0 & 51.0 & 40.7 \\
\hline \multirow{3}{*}{$\begin{array}{l}\text { Ascorbic } \\
\text { acid }\end{array}$} & 50 & 36.0 & 39.6 & 40.8 & 50.0 & 41.6 \\
\hline & 100 & 41.7 & 42.3 & 44.8 & 53.2 & 45.5 \\
\hline & 200 & 39.2 & 46.7 & 47.1 & 46.5 & 44.9 \\
\hline \multirow{3}{*}{$\begin{array}{l}\text { Salicylic } \\
\text { acid }\end{array}$} & 50 & 44.9 & 45.4 & 46.3 & 52.6 & 47.3 \\
\hline & 100 & 46.0 & 49.3 & 49.1 & 52.0 & 49.1 \\
\hline & 200 & 41.3 & 44.3 & 44.9 & 50.0 & 45.1 \\
\hline \multicolumn{2}{|c|}{ Mean (A) } & 40.4 & 43.7 & 44.7 & 50.8 & \\
\hline L.S. & & $\mathbf{A}=$ & & $B=2.0$ & \multicolumn{2}{|c|}{$\mathrm{AB}=\mathbf{4 . 0}$} \\
\hline
\end{tabular}


The combined effect between the two factors on umbels number plant of fennel was statistically significant in both seasons. (Table 4). The most effective treatment was detected due to receiving the plants the high level of compost $+100 \mathrm{ppm}$ ascorbic acid in comparison with those obtained by other combination treatments in both seasons.

\section{Fruit yield/plant and per fed:}

The obtained data in Tables (5 and 6) indicated that with increasing the level of compost significantly increased fruit yield/plant and/fed. of fennel in the two seasons. Obviously, the addition of compost at the high level $\left(24 \mathrm{~m}^{3} / \mathrm{fed}\right)$ produced the maximum value of fruit yield/plant and per fed. sa recorded it by $31.8 \%$ and $35.8 \%$ over the check treatment in the firest and second seasons, respectively.

The positive effect of organic manure on augmenting fruit yield was reported by Sharaf and Khattab (2004) and Azzaz et al. (2009) on fennel and Abou-Aly and Gomma (2002) and Radwan and Farahat (2002) on coriander.
As for ascorbic acid and salicylic acid treatments, the recorded data in Tables (5 and 6) shows that fruit yield/plant and per fed. of fennel was significantly increased resulting from a foliar spray with the two examined materials at all concentrations in both seasons, comparing to untreated ones, except salicylic acid at the low concentration $(50 \mathrm{ppm})$ and the high one $(200 \mathrm{ppm})$ in the first season. In this concern, utilizing the medium concentration of ascorbic acid $(100 \mathrm{ppm})$ registered the heaviest fruit yield/plant and per fed. as recorded $25 \%$ and $25.8 \%$ over control in the first and second seasons, respectively.

The increase in fruit yield due to applying ascorbic acid was detected by Tanious (2008) on fennel, Kenawy (2010) on Ammi visnaga and Ghahory (2012) on Nigella sativa. The stimulating effect of salicylic acid on enhancing fruit yield was studied by Tanious (2008) on fennel, Badran et al. (2011 and 2013) and Rekaby (2013) on coriander and Hemdan (2008) on anise. 
Table 5. The influence of compost levels and treatments of ascorbic and salicylic acids on fruit yield (g)/plant of fennel during 2012/2013 and 2013/2014 seasons.

\begin{tabular}{|c|c|c|c|c|c|c|}
\hline \multicolumn{7}{|c|}{ First season } \\
\hline \multirow{2}{*}{\multicolumn{2}{|c|}{$\begin{array}{c}\text { Antioxidant } \\
\text { concentrations } \\
\text { (B) ppm }\end{array}$}} & \multicolumn{4}{|c|}{ Compost levels (A) } & \multirow{2}{*}{$\begin{array}{c}\text { Mean } \\
\text { (B) }\end{array}$} \\
\hline & & Control & $8 \mathrm{~m}^{3}$ & $16 \mathrm{~m}^{3}$ & $24 \mathrm{~m}^{3}$ & \\
\hline \multicolumn{2}{|c|}{ Control 0 } & 45.7 & 54.7 & 58.0 & 60.0 & 54.6 \\
\hline \multirow{3}{*}{ Ascorbic acid } & 50 & 50.8 & 58.5 & 74.6 & 78.3 & 65.6 \\
\hline & 100 & 53.8 & 60.5 & 77.2 & 81.6 & 68.3 \\
\hline & 200 & 57.2 & 61.5 & 70.2 & 74.0 & 65.7 \\
\hline \multirow{3}{*}{ Salicylic acid } & 50 & 50.0 & 54.3 & 56.4 & 58.5 & 54.8 \\
\hline & 100 & 52.5 & 55.6 & 58.0 & 61.9 & 57.0 \\
\hline & 200 & 50.5 & 51.9 & 57.3 & 60.9 & 55.2 \\
\hline \multicolumn{2}{|c|}{ Mean (A) } & 51.5 & 56.7 & 64.5 & 67.9 & \\
\hline \multicolumn{2}{|c|}{ L.S.D $(0.05)$} & \multicolumn{2}{|c|}{$A=1.5$} & \multicolumn{2}{|l|}{$B=1.5$} & $\mathrm{AB}=\mathbf{3 . 0}$ \\
\hline \multicolumn{7}{|c|}{ Second season } \\
\hline \multirow{2}{*}{\multicolumn{2}{|c|}{$\begin{array}{l}\text { Antioxidant } \\
\text { concentrations } \\
\text { (B) } \mathrm{ppm}\end{array}$}} & \multicolumn{4}{|c|}{ Compost levels (A) } & \multirow{2}{*}{$\begin{array}{c}\text { Mean } \\
\text { (B) }\end{array}$} \\
\hline & & Control & $8 \mathrm{~m}^{3}$ & $16 \mathrm{~m}^{3}$ & $24 \mathrm{~m}^{3}$ & \\
\hline \multicolumn{2}{|c|}{ Control 0 } & 53.3 & 58.5 & 61.3 & 79.1 & 63.1 \\
\hline \multirow{3}{*}{ Ascorbic acid } & 50 & 61.2 & 66.0 & 64.0 & 87.8 & 69.8 \\
\hline & 100 & 72.5 & 72.8 & 78.2 & 94.0 & 79.4 \\
\hline & 200 & 59.5 & 72.6 & 85.6 & 90.5 & 77.1 \\
\hline \multirow{3}{*}{ Salicylic acid } & 50 & 62.3 & 67.5 & 74.3 & 86.0 & 72.5 \\
\hline & 100 & 66.6 & 73.4 & 79.3 & 79.8 & 74.8 \\
\hline & 200 & 62.2 & 60.8 & 63.3 & 77.0 & 65.8 \\
\hline \multicolumn{2}{|c|}{ Mean (A) } & 62.5 & 67.4 & 72.3 & \multirow{2}{*}{\multicolumn{2}{|c|}{$\mathbf{A B}=\mathbf{2 . 0}$}} \\
\hline L.S.D & & $\mathbf{A}=$ & & $B=1.0$ & & \\
\hline
\end{tabular}

Table 6. The influence of compost levels and treatments of ascorbic and salicylic acids on fruit yield ton/feddan of fennel during 2012/2013 and 2013/2014 seasons.

\begin{tabular}{|c|c|c|c|c|c|c|}
\hline \multicolumn{7}{|c|}{ First season } \\
\hline \multirow{2}{*}{\multicolumn{2}{|c|}{$\begin{array}{c}\text { Antioxidant } \\
\text { concentrations } \\
\text { (B) ppm }\end{array}$}} & \multicolumn{4}{|c|}{ Compost levels (A) } & \multirow{2}{*}{$\begin{array}{l}\text { Mean } \\
\text { (B) }\end{array}$} \\
\hline & & Control & $8 \mathrm{~m}^{3}$ & $16 \mathrm{~m}^{3}$ & $24 \mathrm{~m}^{3}$ & \\
\hline \multicolumn{2}{|c|}{ Control } & 1.523 & 1.823 & 1.933 & 2.000 & 1.820 \\
\hline \multirow{3}{*}{ Ascorbic acid } & 50 & 1.693 & 1.950 & 2.487 & 2.610 & 2.185 \\
\hline & 100 & 1.793 & 2.017 & 2.573 & 2.720 & 2.276 \\
\hline & 200 & 1.907 & 2.050 & 2.340 & 2.447 & 2.186 \\
\hline \multirow{3}{*}{ Salicylic acid } & 50 & 1.667 & 1.810 & 1.880 & 1.950 & 1.827 \\
\hline & 100 & 1.750 & 1.854 & 1.933 & 2.062 & 1.900 \\
\hline & 200 & 1.683 & 1.730 & 1.910 & 2.030 & 1.838 \\
\hline \multicolumn{2}{|c|}{ Mean (A) } & 1.717 & 1.891 & 2.151 & 2.260 & \\
\hline \multicolumn{2}{|c|}{ L.S.D $_{(0.05)}$} & \multicolumn{2}{|c|}{$\mathbf{A}=\mathbf{0 . 0 4 4}$} & \multicolumn{2}{|l|}{$B=0.055$} & $\mathrm{AB}=0.110$ \\
\hline \multicolumn{7}{|c|}{$\begin{array}{c}\text { Second season } \\
\end{array}$} \\
\hline \multirow{2}{*}{\multicolumn{2}{|c|}{$\begin{array}{l}\text { Antioxidant } \\
\text { concentrations } \\
\text { (B) ppm }\end{array}$}} & \multicolumn{4}{|c|}{ Compost levels (A) } & \multirow{2}{*}{$\begin{array}{c}\text { Mean } \\
\text { (B) }\end{array}$} \\
\hline & & Control & $8 \mathrm{~m}^{3}$ & $16 \mathrm{~m}^{3}$ & $24 \mathrm{~m}^{3}$ & \\
\hline \multicolumn{2}{|c|}{ Control 0} & 1.777 & 1.950 & 2.043 & 2.636 & 2.102 \\
\hline \multirow{3}{*}{ Ascorbic acid } & 50 & 2.040 & 2.200 & 2.133 & 2.927 & 2.325 \\
\hline & 100 & 2.417 & 2.409 & 2.607 & 3.133 & 2.642 \\
\hline & 200 & 1.983 & 2.420 & 2.853 & 3.017 & 2.568 \\
\hline \multirow{3}{*}{ Salicylic acid } & 50 & 2.077 & 2.250 & 2.477 & 2.867 & 2.418 \\
\hline & 100 & 2.210 & 2.447 & 2.643 & 2.660 & 2.490 \\
\hline & 200 & 2.073 & 2.026 & 2.110 & 2.567 & 2.194 \\
\hline \multicolumn{2}{|c|}{ Mean (A) } & 2.082 & 2.243 & 2.409 & 2.830 & \\
\hline L.S.D & & $\mathbf{A}=$ & & $B=0.032$ & \multicolumn{2}{|c|}{$\mathrm{AB}=0.064$} \\
\hline
\end{tabular}


According to the interacting between the two examined factors, data in Tables (5 and 6) appeared significant effects on fruit yield/plant and per fed. of fennel in both seasons. Obviously, fertilizing fennel plants with the most combined treatments caused a significant increase in fruit yield/plant and per fed. as compared to untreated plants in the two experimental seasons. Supplying the plants with compost at the high level (24 $\left.\mathrm{m}^{3} / \mathrm{fed}\right)+100 \mathrm{ppm}$ ascorbic acid was the most effective treatment in comparison with that obtained by other combination treatments in the two consecutive seasons.

\section{Volatile oil production: \\ Volatile oil \%:}

The listed data in Table (7) clearly that the application of organic manure (compost) at all levels in both seasons except the low level in the two seasons, significantly increased volatile oil \% in fennel fruits as composed to no sprayed control. The maximum value of volatile oil \% was obtained by using compost at the high level $\left(24 \mathrm{~m}^{3} / \mathrm{fed}\right)$ which increased it by $36.6 \%$ and by $15 \%$ over ones in the first and the second seasons, re- spectively. The role of organic manure in augmenting volatile oil \% was insured by Shaalan (2005) and Somida et al. (2001) on Nigella sativa, Ali et al. (2014) on Cassia acutifolia and Rekaby (2013) on coriander.

With respect to ascorbic acid and salicylic acid treatments, the revealed data in Table (7) emphasized that all of them, in both seasons, except salicylic acid at 100 and 200 ppm in the first season led to a significant augment in volatile oil \% as compared to the check treatment. The use of ascorbic acid at the high concentration $(200 \mathrm{ppm})$ gave the maximum value of volatile oil \% as ranged $23 \%$ and $25.4 \%$ over control in the two experimental seasons respectively. The positive effect of ascorbic acid on augmenting volatile oil \% was studied by Tanious (2008) and Eshak (2013) on caraway. The promoting effect of salicylic acid on enhancing volatile oil \% was reported by Abdou et al. (2012) on cumin, Tanious (2008) on fennel and Hassan et al. (2010) on coriander. 
Table 7. The influence of compost levels, ascorbic acid and salicylic acid treatments on volatile oil $(\%)$ in the fruit of fennel during 2012/2013 and 2013/2014 seasons.

\begin{tabular}{|c|c|c|c|c|c|c|}
\hline \multicolumn{7}{|c|}{ First season } \\
\hline \multirow{2}{*}{\multicolumn{2}{|c|}{$\begin{array}{l}\text { Antioxidant } \\
\text { concentrations } \\
\text { (B) ppm }\end{array}$}} & \multicolumn{4}{|c|}{ Compost levels (A) } & \multirow{2}{*}{$\begin{array}{l}\text { Mean } \\
\text { (B) }\end{array}$} \\
\hline & & Control & $8 \mathrm{~m}^{3}$ & $16 \mathrm{~m}^{3}$ & $24 \mathrm{~m}^{3}$ & \\
\hline \multicolumn{2}{|c|}{ Control 0 } & 1.88 & 1.73 & 2.48 & 2.63 & 2.18 \\
\hline \multirow{3}{*}{ Ascorbic acid } & 50 & 1.93 & 2.20 & 2.60 & 2.77 & 2.37 \\
\hline & 100 & 2.15 & 2.49 & 2.78 & 2.93 & 2.59 \\
\hline & 200 & 2.17 & 2.60 & 2.87 & 3.07 & 2.68 \\
\hline \multirow{3}{*}{ Salicylic acid } & 50 & 1.93 & 1.93 & 2.85 & 2.91 & $r, \varepsilon)$ \\
\hline & 100 & 1.95 & 2.03 & 2.30 & 2.40 & 2.17 \\
\hline & 200 & 1.90 & 1.83 & 2.05 & 2.33 & 2.03 \\
\hline \multicolumn{2}{|c|}{ Mean (A) } & 1.99 & 2.12 & 2.56 & 2.72 & \\
\hline \multicolumn{2}{|c|}{ L.S.D ${ }_{(0.05)}$} & \multicolumn{2}{|c|}{$A=0.25$} & \multicolumn{2}{|l|}{$B=0.15$} & $\mathrm{AB}=0.29$ \\
\hline \multicolumn{7}{|c|}{ Second season } \\
\hline \multirow{2}{*}{\multicolumn{2}{|c|}{$\begin{array}{l}\text { Antioxidant } \\
\text { concentrations } \\
\text { (B) ppm }\end{array}$}} & \multicolumn{4}{|c|}{ Compost levels (A) } & \multirow{2}{*}{$\begin{array}{l}\text { Mean } \\
\text { (B) }\end{array}$} \\
\hline & & Control & $8 \mathrm{~m}^{3}$ & $16 \mathrm{~m}^{3}$ & $24 \mathrm{~m}^{3}$ & \\
\hline \multicolumn{2}{|c|}{ Control 0} & 2.10 & 2.33 & 2.25 & 2.42 & 2.28 \\
\hline \multirow{3}{*}{ Ascorbic acid } & 50 & 2.45 & 2.68 & 2.73 & 2.88 & 2.69 \\
\hline & 100 & 2.47 & 2.83 & 2.90 & 2.95 & 2.79 \\
\hline & 200 & 2.72 & 2.63 & 3.00 & 3.10 & 2.86 \\
\hline \multirow{3}{*}{ Salicylic acid } & 50 & 2.43 & 2.52 & 2.68 & 2.86 & 2.62 \\
\hline & 100 & 2.36 & 2.76 & 2.72 & 2.60 & 2.61 \\
\hline & 200 & 2.34 & 2.50 & 2.92 & 2.55 & 2.58 \\
\hline \multicolumn{2}{|c|}{ Mean (A) } & 2.41 & 2.61 & 2.74 & 2.77 & \\
\hline L.S.D & & $\mathbf{A}=$ & & $\mathrm{B}=0.22$ & \multicolumn{2}{|c|}{$\mathrm{AB}=0.45$} \\
\hline
\end{tabular}

The interaction between the two studied factors was statistically significant on volatile oil $\%$ of fennel fruits in the two experimental seasons. However, it is clear that the most of combined treatments caused a significant augment in volatile oil $\%$ as compared to untreated plants in the two seasons. Treating fennel plants with $24 \mathrm{~m}^{3} / \mathrm{fed}$ compost in combination with 200 ppm ascorbic acid registered the maximum value of this trait in comparison with that obtained by other combination treatments in both seasons, as clearly declared in Table (7) Essential oil yield/plant and/fed:
The registered data in Tables ( 8 and 9) postulated that supplying fennel plants with compost at all levels, in both seasons, led to a significant increase in volatile oil yield/plant and/fed. comparing to the check treatment. The maximum values of volatile oil yield/plant was obtained due to applying the high level of compost which augmented it by $80 \%$ and $62.7 \%$ over unfertilized ones in the first and the second seasons, respectively. The positive effect of organic manure on augmenting volatile oil yield was reported by Abdou and Mahmoud (2003) and Sharaf and Khattab (2004) on fennel. 
Table 8. The influence of compost levels and treatments of ascorbic and salicylic acids on volatile oil $(\mathrm{ml}) /$ plant of fennel during 2012/2013 and 2013/2014 seasons.

\begin{tabular}{|c|c|c|c|c|c|c|}
\hline \multicolumn{7}{|c|}{ First season } \\
\hline \multirow{2}{*}{\multicolumn{2}{|c|}{$\begin{array}{l}\text { antioxidant } \\
\text { Concentrations } \\
\text { (B) ppm }\end{array}$}} & \multicolumn{4}{|c|}{ compost levels (A) } & \multirow{2}{*}{$\begin{array}{c}\text { Mean } \\
\text { (B) }\end{array}$} \\
\hline & & Control & $8 \mathrm{~m}^{3}$ & $16 \mathrm{~m}^{3}$ & $24 \mathrm{~m}^{3}$ & \\
\hline \multicolumn{2}{|c|}{ Control 0} & 0.86 & 0.95 & 1.44 & 1.58 & 1.21 \\
\hline \multirow{3}{*}{ Ascorbic acid } & 50 & 0.98 & 1.28 & 1.94 & 2.16 & 1.59 \\
\hline & 100 & 1.16 & 1.50 & 2.14 & 2.40 & 1.80 \\
\hline & 200 & 1.24 & 1.60 & 2.01 & 2.27 & 1.78 \\
\hline \multirow{3}{*}{ Salicylic acid } & 50 & 0.97 & 1.05 & 1.61 & 1.70 & 1.33 \\
\hline & 100 & 1.02 & 1.13 & 1.33 & 1.48 & 1.24 \\
\hline & 200 & 0.96 & 0.95 & 1.17 & 1.42 & 1.13 \\
\hline \multicolumn{2}{|c|}{ Mean (A) } & 1.03 & 1.21 & 1.66 & 1.86 & \\
\hline \multicolumn{2}{|c|}{ L.S.D $(0.05)$} & \multicolumn{2}{|c|}{$A=0.15$} & \multicolumn{2}{|l|}{$\mathrm{B}=\mathbf{0 . 1 0}$} & $\mathrm{AB}=0.19$ \\
\hline \multicolumn{7}{|c|}{ Second season } \\
\hline \multirow{2}{*}{\multicolumn{2}{|c|}{$\begin{array}{l}\text { antioxidant } \\
\text { concentrations } \\
\text { (B) ppm }\end{array}$}} & \multicolumn{4}{|c|}{ compost levels $(A)$} & \multirow{2}{*}{$\begin{array}{c}\text { Mean } \\
\text { (B) }\end{array}$} \\
\hline & & Control & $8 \mathrm{~m}^{3}$ & $16 \mathrm{~m}^{3}$ & $24 \mathrm{~m}^{3}$ & \\
\hline \multicolumn{2}{|c|}{ Control 0} & 1.12 & 1.37 & 1.38 & 1.91 & 1.45 \\
\hline \multirow{3}{*}{ Ascorbic acid } & 50 & 1.50 & 1.77 & 1.75 & 2.53 & 1.89 \\
\hline & 100 & 1.79 & 2.06 & 2.27 & 2.77 & 2.22 \\
\hline & 200 & 1.62 & 1.91 & 2.57 & 2.80 & 2.23 \\
\hline \multirow{3}{*}{ Salicylic acid } & 50 & 1.52 & 1.70 & 1.99 & 2.46 & 1.92 \\
\hline & 100 & 1.57 & 2.02 & 2.15 & 2.08 & 1.96 \\
\hline & 200 & 1.45 & 1.52 & 1.85 & 1.97 & 1.70 \\
\hline \multicolumn{2}{|c|}{ Mean (A) } & 1.45 & 1.77 & 1.99 & 2.36 & \\
\hline \multicolumn{2}{|c|}{ L.S.D $_{(0.05)}$} & \multicolumn{2}{|c|}{$\mathrm{A}=\mathbf{0 . 0 8}$} & $\mathrm{B}=\mathbf{0 . 1 7}$ & \multicolumn{2}{|c|}{$\mathrm{AB}=0.34$} \\
\hline
\end{tabular}

Table 9. The influence of Compost levels and treatments of Ascorbic and Salicylic acids on volatile oil (L) per feddan of fennel during 2012/2013 and 2013/2014 seasons.

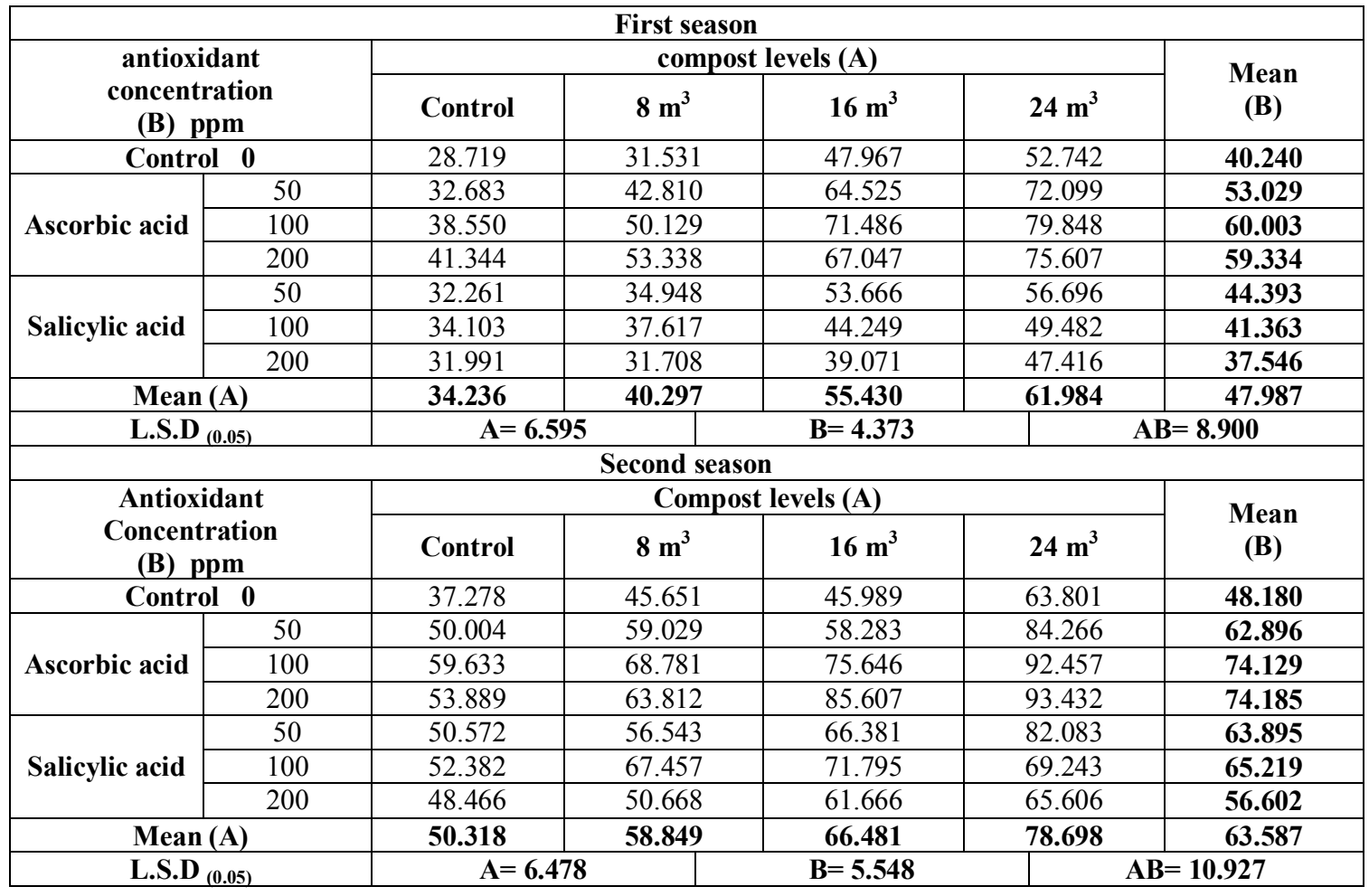


It worthy mention that a foliar spray with ascorbic acid and salicylic acid at all concentrations, in the two seasons, except 100 and $200 \mathrm{ppm}$ salicylic acid in the first season led to a significant increase in volatile oil yield/plant and/fed. of fennel in comparison with no sprayed plants. Obviously, it could be noticed that utilizing $100 \mathrm{ppm}$ ascorbic acid produced the best result of volatile oil yield/plant and fed. reached 48.7\% and $53 \%$ over untreated ones in the two growing seasons, respectively, as clearly indicated in Tables (8 and 9). The positive effect of ascorbic acid on augmenting volatile oil yield was studied by Tanious (2008) on fennel and Abd El-Naeem (2008) and Eshak (2013) on caraway. The promoting effect of salicylic acid on enhancing volatile oil yield was reported by $\mathrm{Ab}$ dou et al. (2012) on cumin, and Tanious (2008) on fennel. As far as the combined effect on volatile oil yield/plant and/fed. of fennel, the listed data in Tables (8 and 9) revealed that there were statistically significant differences in the two experimental seasons. It is obvious that these traits were significantly augmented as a result of using the most combined treatments in comparison with untreated plants in the two seasons. However, the treatment with compost at the high level plus ascorbic acid at $100 \mathrm{ppm}$ produced the better values of volatile oil yield/plant and/fed. as compared to these obtained by other combination treatments in both seasons.

From the obtained results, it could be discussed as follows: The promoting effect of organic manure on growth, fruit yield and oil production of fennel plants may be attributed to the role of organic fertilizer in physiological and biological process whereas, Bohn et al. (1985) emphasized that organic matter as a source of $\mathrm{N}, \mathrm{P}, \mathrm{S}$ and contains high content of $\mathrm{B}$ and Mo. In addition organic matter has source of energy for Azotobacter growth. Follet et al. (1981) demonstrated that some of beneficial effect of organic manure for example: enhancing soil properties, water holding capacity and increasing total $\mathrm{N}$, organic matter and humus in soil as well as releasing essential nutrients by microbial decomposition and also making frost micronutrients more readily available at a wide range of $\mathrm{pH}$. Taiwo et al. (2002) reported that microbial activities in root zone was increased by the application of organic manure. Humic substances have to be direct influence on growth which assuming a hormonal action of humic substances (Varanini and Pinton, 1995). The same previous authors showed that soil organic matter supplies nutrients, it is a buffer against $\mathrm{pH}$ change it protects against salt toxicity and heavy metal, it prevents leaching of nutrients and it supports microorganisms which recycle nutrients and the formation of soil. The enhancement of growth, fruit yield and oil production of fennel due to applying ascorbic acid and salicylic acid might be attributed to the positive, biological and physiological roles of these substances, where that ascorbic acid is considered as an antioxidant that protect the plant against damage as a result of aerobic metabolism and pollutants range. It is involved in establishing the local and systemic disease resistance response of plants after pathogen attack (Alvarez, 2000). It induce flowering retard senescence and augment the rate of cell metabolic and the sustained level of salicylic acid may be a prerequisite for auxin 
and/or it plays an important role as coenzyme. Also, it is a significant resistance against many plant pathogens i.e. bacteria, fungi, nematode and parasitic plants (Oertil, 1987 and Mahdy, 1994). As for salicylic acid, it is classified as a plant hormone (Raskin, 1992). It plays regulatory role in plant metabolism (Popova et al., 1997). Romani et al. (1989) proved that salicylic acid affects the biosynthesis of ethylene, stomatal movement and reserves the influence of ABA on leaf abscission.

\section{References}

Abd El-Gawad, M.H. (2007). Effect of some organic and biofertilization treatments on vegetative growth and chemical composition of coriander plants. Ph.D. thesis, Fac. Agric., Minia Univ.

Abd El-Naeem, L.A. (2008). Response of caraway plants to some organic and biofertilization treatments. M.Sc. Thesis, Fac. Agric., Minia Univ.

Abdallah, N.; S. El-Gengaine and E. Sedrok (1978). The effect of fertilizer treatments on yield of seed and volatile oil of fennel (Foeniculum vulgare Mill). Pharmazie. 33 (9): 607-608.

Abdou, M.A.; Taha, R.A.; R.M. SalahEldeen R.M. and Abd- Elraouf, R.M. (2012a). Influence of organic, NPK, biofertilization and natural substance treatments on black cumin plants. Proc. Sec. Intern. Conf. of Physical, Microbiological and Ecological Plant Sci., April 29-30, Fac. of Sci., Minia Univ.

Abdou, M.A.H.; Taha, R.A.; Abd ElRaaof, R.M. and Salah El-Deen, R.M. (2012b). Response of fennel plants to organic, bio and mineral fertilization. Proc. Second Inter. Conf. Physiological, Microbiological and Ecological Plant Sciences, (April 29th-30th) Fac. of science, Minia Univ.
Abdou, M.A.H. and M.A. Mohamed (2003). Growth and oil production of Foeniculum vulgare, Mill. 2The effect of number of irrigation and fertilizers. J. Agric. Sci. Mansoura Univ., 28 (5): 4553-4563.

Abo-Aly, H.E. and A.O. Gomaa (2002). Influence of combined inoculation with diazotrophs and phosphate solubilizers on growth yield and volatile oil content of coriander plants (Coriandrum sativum, L.). Bulletin of Fac. of Agric., Cairo Univ., 53 (1): 93-113.

Abou El-Fadl, I.A.; M. Abou-Baker and A.M. El-Gamal (1990). Effect of different organic manure composis on roselle (Hibiscus sabdarrifa L.) plants and soil characteristics. Agric. Res. Review., 68 (5): 10771087.

Ali, A.F. (2004). The benefits of using some natural sources of phosphate and salicylic acid on Tagetes minuta, L. plants. Minia J. of Agric. Res. \& Dev., 24 (4): 621-648.

Ali, A.F.; E.A., Hassan; E.H. Hamad and M.F. Ibrahim (2014). Response of Cassia acutifolia plants to some fertilization treatments. J. Biol. Chem. Environ. Sci., 2014, Vol. 9 (1): 561-583.

Ali, A.F.; M.R. Khater and G.H. Abd-ElRahem (2003). Response of coriander plants to orthophosphoric acid, Thiamine and Ascorbic acid treatments. Proc. $1^{\text {st }}$ Egypt \& Syr. Conf. for Agric. \& Food, El-Minia, Dec. 8-11, 2003, Vol. No. 2, (4559).

Ali, A.F.; N.A. Azzaz and E.A. Hassan (2006). Influence of spraying active dry yeast, methionine and ascorbic acid on growth, yield and oil of anise (Pimpinella anisum, L.) plants. Minia J. of Agric. Res. \& Develop. Vol. (26) No. 4 pp. 684-716, 2006.

Al-Shareif, A.M. (2006). Response of caraway plants grown in sandy soil under drip irrigation system to some biofertilization and antioxi- 
dant treatments. M.Sc. Thesis, Fac. Agric., Minia Univ.

Alvarez, M.E. (2000). Salicylic acid in the machinery of hypersensitive cell death and disease resistance. Plant Mol. Biol., 44: 429-442.

Azzaz, N.A.; E.A. Hassan and E.H. Hamed (2009). The chemical constituent and vegetative and yielding characteristics of fennel plants treated with organic and biofertilizer instead of mineral fertilizer. Australian J. of Basic and Applied Sci., 3 (2): 679-587.

Badran, F.S. and M.S. Safwat (2004). Response of fennel plants to organic manure and bio-fertilizers in replacement of chemical fertilization. Egypt. J. Agric. Res., 82 (2): 247-256.

Badran, F.S.; Attia, F.A. and Ayat, A.M. (2011). Response of coriander (Coriandum sativum, L.) plants, grown in new reclaimed land to NPK fertilization and antioxidant treatment. Inter. Conf. on total Quality Management of herb \& medicinal Plants and their products, Egypt, Inter. Center of Agric, Egypt, Dec. 6-8, 2011.

Badran, F.S.; Attia, F.A. and Ayat, A.M. (2013). Effect of macro/micro fertilization treatment as well as, Salicylic and ascorbic acid on growth, fruit yield and essential oil of coriander. Plants grown in sandy soil. The first Assiut Inter. Conf. of Horticulture. $24-27^{\text {th }}$ Feb., 2013.

Bohn, H.L.; B.L. Meneal and G.A.O. Connar (1985). Soil chemistry $2^{\text {nd }}$ ed. A Wiley Interscience Publication. John Wiley and Sons, New York.

Charles, D.J.; M.R. Morales and J.E. Simon (1993). Essential oil content and chemical composition of finocchlo fennel. In Janick J. and J.E. Simon (eds). New Crops Wiley New Crops. Wiley New York. Pp. 570-573.
Chjej, R. (1984). The Macdonald Encyclopedia of Medicinal Plants. MacDonald \& Co., London.

Eshak, W.S. (2013). Physiological studies on caraway plants. M.Sc. Thesis, Fac. of Agric., Minia Univ.

Farrell, K.T. (1988). Spices. Condiments and seasoning. Art Publ. Westport, CT., pp. 106-109.

Follet, R.H.; L.S. Murphy and R.I. Donahue (1981). Fertilizers and Soil Amendments. Prentice Hall, Inc., Inglewood Cliffs, N.J. USA.

Gahory, A.M. (2012). Physiological studies on black cumin plant. Ph.D. Diss., Fac. of Agric., Minia Univ.

Guenther, E. (1961). "The Essential Oils" Vol (1): D. Von No strand Comp., New York, pp. 236.

Hassan, E.A.; A.F.Ali and A.E. ElGohary (2015). Enhancement of growth, yield and chemical constituents of Rosemary (Rossmarinus officinalis, L.) plants by Application of Compost and Bio fertilization Treatments. Middle East J. of Agric. Res. Vol. 4, Issue: 01, Jan.-Mar. 2015, pages 99-111.

Hassan, E.A.; E.F. Ali and A.F. Ali (2010). The enhancement of plant growth, yield and some chemical constituents of dill (Anethum graveolens, L.). Plants by filter mud and Applied Sci., 4 (5): 948956.

Hemdan, Sh.H. (2008). Effect of some organic and biofertilization treatments on anise plants. M.Sc. thesis, Fac. Agric., Minia Univ.

Kenawy, A.G. (2010). Response of Ammi visnaga, L. plants to some organic and bio-fertilization treatments. Ph.D. Thesis, Fac. of Agric., Minia Univ.

Lawless, J. (1997). The illustrated encyclopodia of essential oils. The complete guide to the use of oils in aromatherapy and herbatism buttler \& Tammer Lid, from and London British Laboratory Cataloguing in Publication data avail. 
Little, I.M. and S.J. Hills (1978). Agricultural Experimentation, Design and Analysis. John Wily \& Sons, Inc. New York, U.S.A.

Mahdy, M.C. (1994). Plant Physiology, p. 105 and 467.

Mohamed, A.A. and M.E. Ahmed (2003). A comparative study on the effect of sugarcane filter mud, sheep and chicken manures used for fertilization of sweet fennel (Foeniculum vulgare L.). Minia J. Agric. Res. \& Dev. 22 (3): 221234.

Oertil, J.J. (1987). Exogenous application of vitamins as regulators on growth and development of cowpea plants. Review, Z-Planzeneranhr, Bodenk, 150: 375-391.

Popova, L.; T. Pancheva and A. Uzunova (1997). Salicylic acid, properties, biosynthesis and physiological role. Bulg. J. Plant Physiology, 23: 85-93.

Radwan, S.M.A. and M.M. Farahat (2002). Grown and yield of coriander plants as affected by bioorganic fertilization and pix application. Egypt. J. Apple., 17: 268286.

Raskin, I. (1992). Salicylate, a new plant hormone. Plant Physiology, 99: 799-803.

Rekaby, A.M. (2013): Improving the productivity of coriander plants by the us of some unconventional treatments. Ph.D. thesis, of Agric. Minia Univ.

Romani, R.J.; V.M. Hess and C.A. Lestie (1989). Salicylic acid inhibition of ethylene production by apple discs and other plant tissues. J. Plant Growth Regulators, 8: 62-69.
Shaalan, M.N. (2005). Influence of biofertilization and chicken manure on growth yield and seeds quality of Nigella sativa sativa L. plants. Egypt. J. Agric. Res., 83 (2): 811 828.

Sharaf, M.S. and M.F Khatab (2004). Effect of fertilization with inorganic, organic and biofertilizer on growth, yield and volatile oil concentration of fennel (Foeniculum vulgare Mill) plants. J. Agric. Sci. Mansoura Univ., 29 (9): 52455264.

Somida, E.G.; F.A. Attia; F.S. Badran and A.A. El-Sayed (2001). Response of Nigella sativa L. plant grown in sandy soil, to some nitrogen and potassium fertilization treatments. Proc. $5^{\text {th }}$ Arabian Hort. Conf., Ismailia, Egypt, March, 2428: 179-194.

Taiwo, L.B.; I.Adediran; J.A.Ashaye; O. Odofin and A.J. Oyadoyin (2002). Organic okrr (Abdolmoschus esculentus): Its growth yield and organoleptic properties. Nutrition \& Food Sci., 32 (415): 180-183. (Hort. Abst. 72 (12): 10918).

Tanious, C.T. (2008). Effect of some organic and biofertilization treatments on fennel plants. M.Sc. Thesis, Fac. Agric., Minia Univ.

Varanini, Z. and R. Pinton (1995). Humic substrates and plant nutrition. Progress in Botany, 56: 79-111.

Wichtl, M. and N.G. Bissel (1994). Herbal drugs and phytopharmaceuticals (eds), Med. Pharm Scientific Publ. Stuttgart, pp. 107-108. 
تأثير معاملات الكمبوست وحامض الأسكوربيك وحامض السالسيليك علي النمو و المحصول

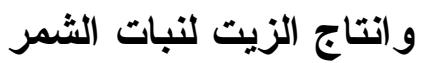

أحمد فؤاد علي، عصام علي حسن، العبد حماد عامر ، وليد محمد حلمي أبوقوطة قسم البساتين - كلية الزراعة - جامعة الأزهر - أسيوط - مصر كلياد

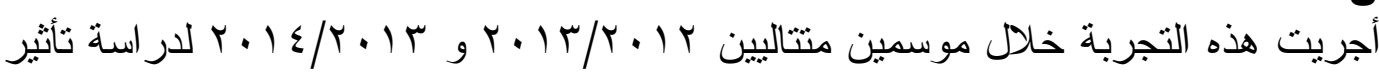

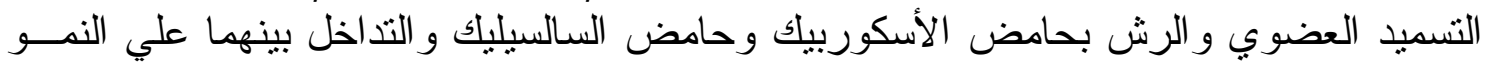

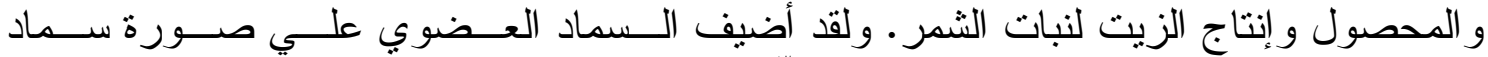

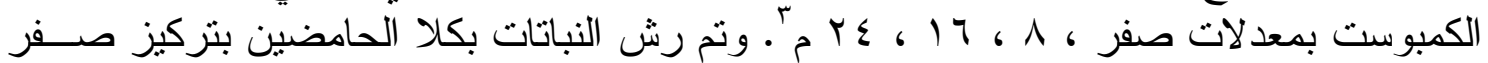

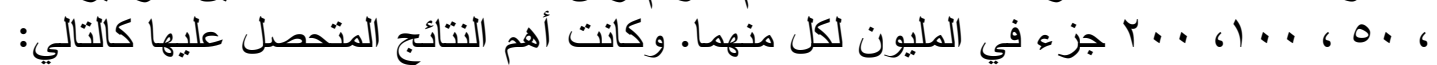

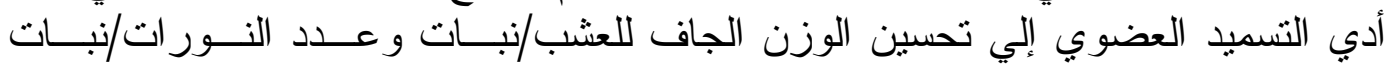

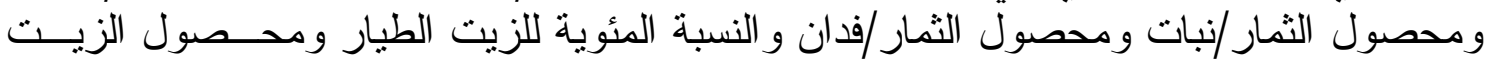

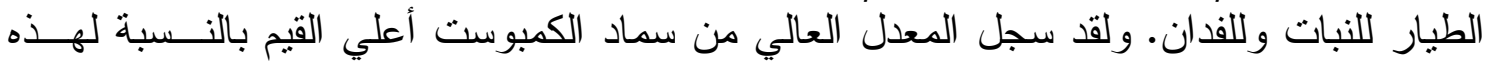

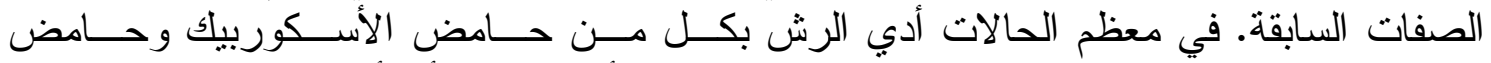

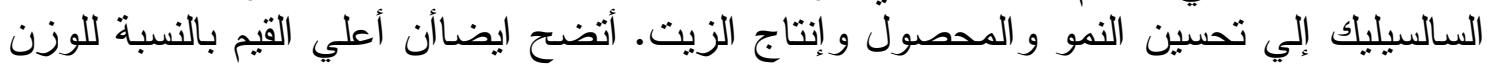

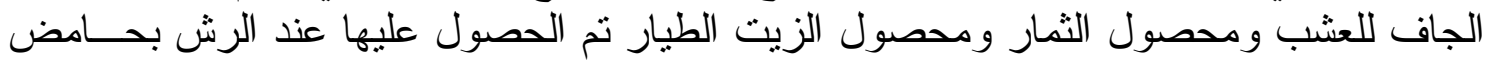

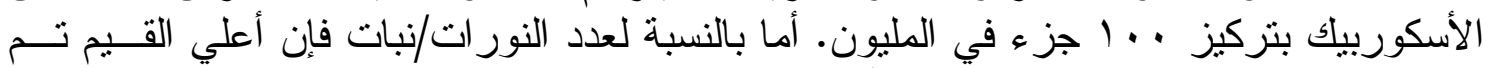

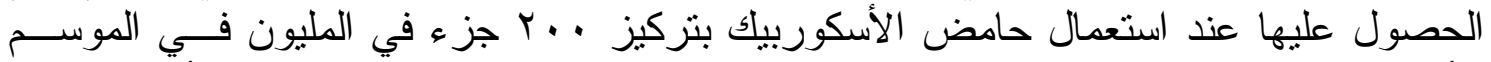

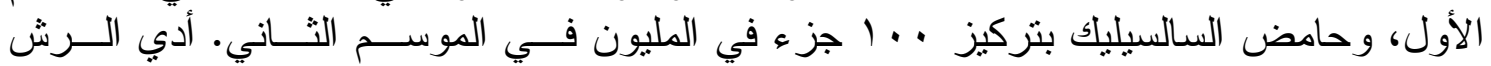

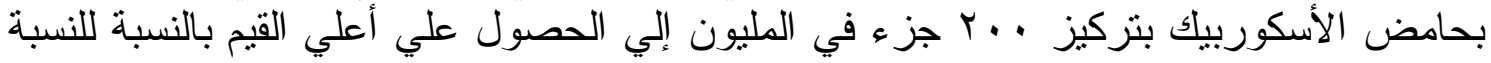

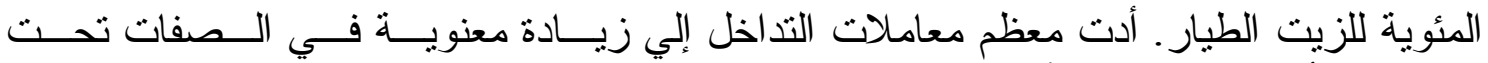

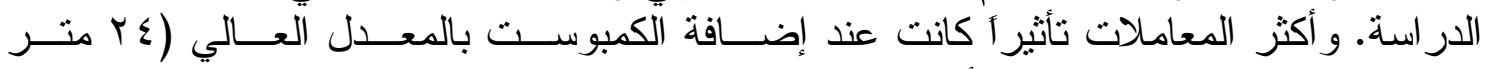

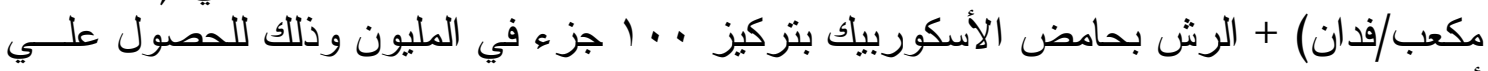

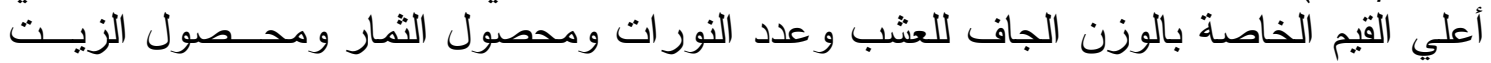

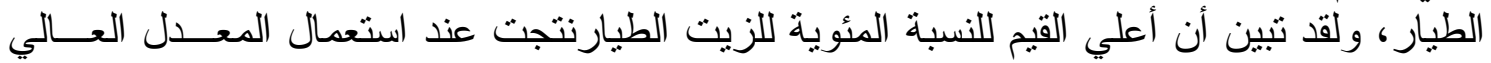

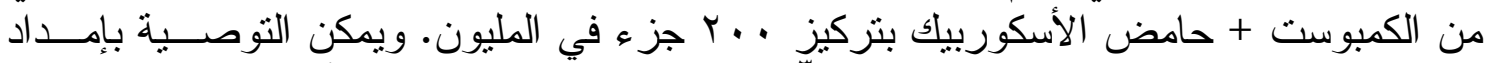

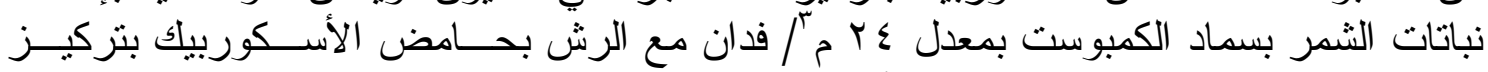

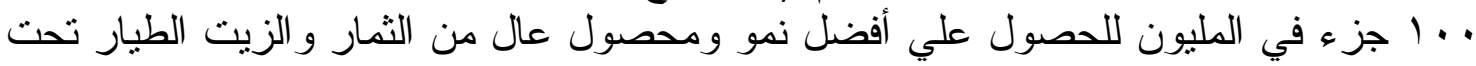

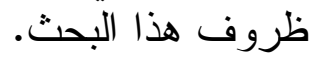

